\title{
Future Pedagogues' Attitudes and Knowledge about Inclusive Education in Spain: An Exploratory Study
}

\author{
Santiago Mengual-Andrés ${ }^{1}$, Manuel López-Torrijo ${ }^{1} \&$ María-Isabel Viana-Orta $^{1}$ \\ ${ }^{1}$ Department of Comparative Education \& History of Education, University of Valencia, Valencia, Spain \\ Correspondence: Santiago Mengual-Andrés Avda. Blasco Ibáñez 30, Faculty of Philosophy and Educational \\ Sciences, Valencia, 46010, Spain. E-mail: Santiago.Mengual@uv.es
}

Received: March 24, 2015 Accepted: May 4, $2015 \quad$ Online Published: June 26, 2015

doi:10.5539/res.v7n11p103 URL: http://dx.doi.org/10.5539/res.v7n11p103

\begin{abstract}
This article analyses the attitudes and knowledge about inclusive education among students reading Pedagogy at the University of Valencia and how these are influenced by participants' age, gender, and which academic programme or year of study they are in. This research comprises a sample of 182 students from the degree's four year groups, which guarantee a representativeness of 95\%. The principal results indicate that attitudes towards inclusive education among students reading Pedagogy are highly positive. However, they consider the training received insufficient. Regarding the participants of the study, the analysis shows that attitudes towards inclusive education are directly related to age, while gender has no influence over students' attitudes.
\end{abstract}

Keywords: inclusive education, attitudes, knowledge, pedagogy, students

\section{Introduction}

We understand Inclusive Education (IE) as a type of education which ensures the exercising of the inalienable right to a complete, quality education for all. It involves every student's full personal development and their maximum integration in society. IE considers students' diversity an enriching element and, thus, promotes it. Finally, IE supports the idea that everyone should be present and participate and interact at school (EADSNE, 2011; Booth \& Aiscow, 2002; López, 2009; López-Torijo \& Mengual-Andrés, 2014; López-Torrijo \& Mengual-Andrés, 2015; Opertti \& Brady, 2011; UNESCO, 2008).

All this has been acknowledged by the international community through declarations which imply an irreversible commitment to IE. Some significant milestones are the Salamanca Statement and Framework for Action on Special Needs Education (UNESCO, 1994); the Declaration of Madrid in 2002, where the 50 million European disabled people were represented by 400 participants; the UN Convention on the Rights of Persons with Disabilities (UN, 2006), which was signed by 147 countries and ratified by 97; and the 48th Session of the International Conference on Education "Inclusive Education: the way of the future" (UNESCO, 2008).

Together with its European partners, Spain has subscribed to all those international declarations and has even been at the forefront of some of them (Rao, Cardona \& Chiner, 2014). At a regulatory level, it has invested a lot into IE. Proof of this is the regulatory process started some decades ago and improved in recent years: the Spanish Constitution (SC, 1978, art. 25 and 49); Law of Social Integration of Disabled People-Ley de Integración Social de los Minusválidos, LISMI-(LISMI, 1982); Organic Law of General Arrangement of the Educational System - Ley Orgánica de Ordenación General del Sistema Educativo, LOGSE_(LOGSE, 1990); Organic Law of Quality of Education_Ley Orgánica de Calidad de la Educación, LOCE_(LOCE, 2002); Law of Equal Opportunities, Non-discrimination and Universal Accessibility of Disabled People-Ley de Igualdad de Oportunidades, No Discriminación y Accesibilidad Universal de las Personas con Discapacidad, LIONDAU-(LIONDAU, 2003). The current Organic Law of Education-Ley Orgánica de Educación, LOE - (LOE, 2006) establishes IE as the Spanish educational model in its principles (art. 1), its aims (art. 2) and in Title II, which is dedicated to "Educational equality".

The education provided to students with SEN is conceived from the perspective of IE. Thus, there is no difference between Special Education and Inclusive Education; actually Special Education is part of Inclusive Education. The principle of individualised attention demands different educational integration degrees adapted to each student's abilities, limitations and needs. That means parents can choose among different modalities and 
types of schooling: ordinary school with no extra support; ordinary school with extra support (inside and outside the classroom); combined schooling (in ordinary and specific students' groups); specific students' groups in ordinary schools and, finally, simply specific schools. The type of schooling should always aim at the best possible modality and level of inclusion for each student and is revised every academic year, sometimes even during the same year.

According to statistical data, Spain is considered one of the EU countries with the highest levels of IE. Only $0.4 \%$ of Spanish students with special educational needs (SEN) attend specific educational institutions (EADSNE, 2011; Chiner \& Cardona, 2012) in contrast to $4 \%$ in Belgium, Denmark, Germany or Switzerland. According to the most recent data from the Ministry of Education, Science and Sports-MECD - 33.447 students are educated in 490 specific institutions at non-university level (0.41\%), compared to 8.087.347 students who attend ordinary schools with different modalities and levels of educational inclusion. $1.9 \%$ of students have SEN $(0.7 \%$ in preschool; $1.9 \%$ in primary school; $2.2 \%$ in compulsory secondary school; $7.0 \%$ in initial qualification programmes, $0.2 \%$ in non-compulsory secondary school-Bachillerato-and $0.4 \%$ in vocational training education) and 755.156 students have foreign origins (9.1\%). Spain has the highest student dropout rate in the EU: $24.9 \%$ in contrast to the EU average of $12.8 \%$. In 2012, there were 664.325 professionals teaching at a non-university level in Spain, which means a student-teacher ratio of $12 \%$ (13.2 \% in primary education; $10.3 \%$ in compulsory secondary school-ESO — and $9.8 \%$ in non-compulsory secondary school-Bachillerato-). In that same year, the Spanish Government invested 47 million euros in education, which was $4.58 \%$ of the gross domestic product (MECD, 2012).

Apart from the teaching professionals working at ordinary schools, students with SEN receive assistance from (early, general and specific) psychopedagogical and educational guidance teams (Equipos de Orientación Educativa y Psicopedagógica), which are allocated on a regional basis. These units are comprised of psychopedagogists, teachers specialised in hearing and language, teachers specialised in therapeutic pedagogy, special education teachers and social workers. Psychopedagogists' specific functions are: (a) to coordinate SEN students' psychopedagogical diagnosis and assessments, from which individualised learning programmes and pedagogical or organisational adaptations are derived; (b) to propose the most suitable schooling modality for each student; and (c) to provide guidance to schools, professionals and families on anything related to the prevention, detection and assistance to students with SEN. Specifically, they provide support to school management teams and teaching staff on the measures, regulations, projects, materials and educational resources which are necessary for IE. Psychopedagogists are, in short, key specialists in the process of IE and coordinators of the psychopedagogical units (Servicios Psicopedagógicos).

The international declarations quoted above highlight the importance of professionals' initial and continuous training, as well as the significance of professionals' attitudes when they deal with students with SEN (UNESCO, 1994, art. 3 and 4; UN, 2006, art. 8, 24.4 and 26.2).

As a result of this, recent studies have tackled those questions. Future professionals' general attitude towards IE is positive (Cook, 2002; Haq \& Mundia, 2012; Loreman, Earle, Sharman, \& Forlin, 2007; Mu, Franck, \& Konz, 2007), even in spite of some professionals' stance denouncing the lack of initial training, time and assistance to address it correctly (Lambe, 2011). Future professionals show a clearer position regarding IE in the case of students with learning disabilities than in the case of students with behavioural problems, mental deficiency or multiple disability (Cook, 2002). Other research shows neutral attitudes towards the social participation of students with disabilities (de Boer, Pijl, \& Minnaert, 2012). And some studies have found a certain rejection towards IE for disabled people in general (Sharma, Moore, \& Sonawane, 2009) and people with sensory, mental, behavioural problems or multiple disabilities (Haq \& Mundia, 2012), and even towards students with low academic performance or with a shy, withdrawn personality (Sharma et al., 2009).

The importance of future professionals' attitude (de Boer, Pijl, \& Minnaert, 2010) lies in the fact that it can, and will, affect their ability to apply inclusive criteria in their professional career (Costello \& Boyle, 2013). However, some elements can help develop a positive attitude towards IE. Indeed, all of the aforementioned studies point to initial training as the main factor (Cook, 2002; Mu et al., 2007), along with professional experience in IE, knowledge about different disabilities (Brandes, McWhirter, Haring, Crowson, \& Millsap, 2012; de Boer et al., 2010; Sharma, Forlin, \& Loreman, 2008), special education training during undergraduate or postgraduate studies (Forlin, Garcia Cedillo, Romero-Contreras, Fletcher, \& Rodriguez Hernandez, 2010; Sharma et al., 2009), training on inclusion policies and regulation (Forlin, Sharma, \& Loreman, 2009), and even personal factors, such as predisposition or talent (Cook, 2002). However, Cook's (2002) study also identifies aspects which can be detrimental to future teachers' attitude towards IE, such as limited teaching experience, knowledge or aptitude in the field of education. 
Regarding future professionals' knowledge about IE, almost all studies mention insufficient training and limited or negative experiences (Forlin \& Chambers, 2011; Forlin et al., 2010; Forlin, Loreman, Sharma, \& Earle, 2009; Gokdere, 2012; Sharma et al., 2009).

Regarding sociodemographic variables related to IE future professionals' attitudes and knowledge, (Forlin, Loreman, et al., 2009) state that female students show a slightly higher positive attitude than male students. However, it is the men who improve their attitude most after training. Similarly, other studies show that younger future professionals' attitude is slightly worse than their older peers (Sharma et al., 2008), though this also improves more than their older classmates after training (Forlin, Loreman, et al., 2009).

As regards the level of education acquired, several studies show that specific IE training courses improve future teachers' attitudes and self-confidence (Glumbic, Kaljaca, \& Brojcin, 2004; Stella, Forlin, \& Lan, 2007), as well as their abilities and self-awareness regarding those abilities (Cologon, 2012). Training in Special Education (Forlin et al., 2010) and in the field of disabilities (Sharma et al., 2008) has also provided an improvement in their attitudes towards people with disabilities. Some studies have detected the training areas which are the cause of future teachers' greatest concerns: assistance to students with low performance, disaffection, anti-social, negative behaviour and, especially, bullying (Kyriacou, Avramidis, Stephens, \& Werler, 2013).

As far as methods are concerned, combined programmes - comprising a theoretical part and a part related to structured experiences - have proved excellent compared to separate programmes (Campbell, Gilmore, \& Cuskelly, 2003; Kim, 2011). However, immersive training courses do not clearly offer better results than short programmes (Sharma et al., 2008).

Students with higher marks or higher qualifications show better attitudes towards people with disabilities than those with lower marks and qualifications (Forlin et al., 2009; Sharma, Forlin, Loreman, \& Earle, 2006). Likewise, slight improvements are found in future professionals' change of attitude as more training is received (Costello \& Boyle, 2013).

Very little research has been carried out for Spain. Gómez and Infante (2004) analysed the attitudes of Spanish students from various university subjects with regard to intercultural and inclusive education. They discovered that all of them showed a positive attitude, with final-year Pedagogy students having a better attitude than Business Engineering students. Sandoval (2009) found shortfalls in training regarding the identification of learning disabilities, teaching responsibilities and cooperation among teaching staff. However, future education professionals showed positive attitudes towards IE, with the development of values such as justice, equality and cooperation. Meanwhile, Llorent and Llorent (2012) studied the semantics of future education professionals from Brazil, Cabo Verde, Seville and Cordoba (Spain) with regards to IE. Their study was carried out through the analysis of documentaries, interviews, free comments and surveys, and they confirmed the relation between their perceptions and the institutional and regulatory context participants were in.

However, future Pedagogy specialists' training and attitudes towards IE have not been researched since the Bologna Process university reforms and that reform affects the initial training of professionals. In that sense, the White Paper for the Degree in Pedagogy and Social Education (a document which provides the framework for the preparation of the new Spanish university degrees since the Bologna process) brought together all the basic skills those professionals should acquire in order to adequately fulfill the functions required for IE (ANECA, 2005).

The University of Valencia is one of the ten Spanish universities included in the Shanghai ranking for 2013. According to the training programme, students on the Pedagogy degree course at this university receive 240 credits (2,400 hours) of training during 4 academic years (of which 200 are theoretical, 32 are practical and 8 are dedicated to the Final Project). In theory, they are gaining the qualifications to diagnose, plan and provide educational guidance in any situation affected by diversity, inequality or discrimination, as well as to promote interculturality.

Quantitatively, however, only 15 credits are dedicated to Inclusive Education in the degree of Pedagogy at University of Valencia, which means $6.25 \%$ of the total. The subjects offered are: a) Intercultural Pedagogy (6 credits, compulsory); b) Diagnosis of students with SEN (4.5 credits, optional) and c) Inclusive Education (4.5 credits, optional). Each credits amounts to 10 learning hours in the Spanish university system.

Using the University of Valencia as the Spanish example, this study brings up the following research questions:

1) Do future pedagogues have positive attitudes towards IE?

2) Do those future professionals consider that they are sufficiently qualified to meet the needs of IE? 
3) To what extent does their age, their gender and the training received at university affect their knowledge and attitudes towards IE?

\section{Method}

\subsection{Participamts}

The sample comprised 182 students - from the degree's four year groups-reading Pedagogy at the Faculty of Philosophy and Educational Sciences of the University of Valencia. Nonprobability sampling procedures were used based on the total sample size, which provided a confidence level of $95.5 \%(\alpha=.05)$.

Most participants were women, $88.4 \%(n=161)$, and only $11.54 \%(n=21)$ of them were men. Participants' age ranged from 19 to 54 , with an average of 21 years old $(M=21.6 ; S D=4.3)$. The sample was created with students from the degree's four year groups: $37.9 \%$ were first-year students, $21.4 \%$ were second-year, $25.8 \%$ were third-year and $14.8 \%$ were fourth-year.

\subsection{Instrumentation}

The Attitudes, Knowledge and Previous Experience about Inclusive Education Questionnaire (AKPEIEQ) was used to examine future professionals' attitudes and knowledge about educational inclusion. This instrument consisted of two parts: (a) the IE Attitude Scale (AS) referred to the dimension "Foundations towards inclusion" from the Teachers' Perceptions on Inclusion Questionnaire developed by Cardona, Gómez-Canet and González-Sánchez (2000) including seven items, and (b) the IE Knowledge Scale (KS), which was designed ad hoc for this study and which comprised seven items. Both dimensions used a five-level Likert scale $(1=$ Strongly disagree, 2 = Disagree, 3 = Undecided, $4=$ Agree, 5 = Strongly agree).

The questionnaire showed high internal consistency $(\alpha=.90)$ and inter-item correlation analyses did not show an increase of reliability through the elimination or alteration of items. Content validity proved appropriate through the use of Lawshe's (1975) content validity index (CVI), showing a global CVI of 0.79 .

\subsection{Procedures}

The AKPEIEQ was distributed in two ways (printed and online) during the second semester of the 2012-2013 academic year. The online version was developed through the Limesurvey software. For the distribution, permission was given by the School of Education and by the different teachers who provided the students with the questionnaire. One researcher explained its content and solved the doubts participants had during completion. The on-line version was provided in order to involve a higher number of participants and so that students who were on their internships could participate if they were interested. Data was collected and recorded during two weeks and the response rate was high, at $96 \%$.

\subsection{Data Analyses}

The data analyses were carried out with SPSS 22 statistical software. Measures of central tendency and dispersion were used to analyse participants' answers about their attitudes and knowledge towards IE. After checking normal distribution and homogeneity of variances for the various contrasts, different parametric measures were used. An independent-samples $t$-test was used to check if there were any differences in attitudes and knowledge based on gender. A one-way between-groups analysis of variance (ANOVA) was implemented to explore the differences among attitudes and knowledge based on students' academic year of study. Last but not least, post-hoc contrasts were used to find out differences among groups, and effect sizes for parametric tests were calculated.

\section{Results}

\subsection{Future Pedagogues' Attitudes and Knowledge towards IE}

Generally speaking, attitudes towards IE were highly favourable $(M=4.35, S D=.8)$. As Table 1 shows, almost all participants $(96.2 \%)$ were in favour of IE and $78.4 \%$ declared themselves to be against educational segregation. Similarly, most participants (96.2\%) believed IE develops tolerance and respect, also in secondary school for $92.3 \%$ of students, pointing out more advantages than disadvantages $(85.2 \%)$. Lastly, $87 \%$ of participants considered the presence of support professionals in the classroom an indispensable element for an efficient IE.

However, participants defined themselves as having very little knowledge $(M=2.9, S D=.9)$ about IE. $42 \%$ of them acknowledged not knowing international or Spanish regulations on IE. Similarly, a high percentage (77\%) considered themselves indecisive or incapable of carrying out an assessment for students with SEN, or admitted having limited ability when it came to providing guidance to students with SEN about their future professional opportunities (72.4\%). At the same time, $67.6 \%$ of participants confirmed they did not know about the different 
inclusive schooling modalities. Nevertheless, $56 \%$ of participants felt qualified to do their job according to the requirements of IE.

Table 1. Students' attitudes and knowledge towards IE

\begin{tabular}{lllllll} 
& & \multicolumn{2}{c}{ Disagree } & \multicolumn{2}{c}{ Unsure } & \multicolumn{2}{c}{ Agree } \\
\cline { 2 - 7 } & $n$ & $\%$ & $f$ & $\%$ & $n$ & $\%$
\end{tabular}

\section{Attitudes towards inclusion}

1. It is unfair to separate students with SEN from the rest of their peers

$\begin{array}{llllllll}4.08 & 1.25 & 24 & 13.2 & 15 & 8.3 & 142 & 78.4 \\ 4.64 & .57 & 1 & 0.5 & 6 & 3.3 & 175 & 96.2 \\ 3.99 & .96 & 18 & 10 & 27 & 14.9 & 136 & 75.2 \\ 4.46 & .68 & 3 & 1.6 & 11 & 6.0 & 168 & 92.3 \\ 4.27 & .86 & 8 & 4.4 & 19 & 10.4 & 155 & 85.2 \\ 4.64 & .55 & - & 0 & 7 & 3.8 & 175 & 96.2 \\ 4.38 & .78 & 4 & 2.1 & 19 & 10.4 & 159 & 87.3 \\ 4.35 & .8 & & & & & & \end{array}$

2. Inclusive education develops tolerance and respect among students

3. I think that all students, including those with moderate and severe disabilities, can learn in inclusive settings

4. Inclusive education is also possible in secondary education

5. Inclusion has more advantages than disadvantages

6. I am in favour of inclusion

7. Inclusion requires the presence in the classroom of support educators

Total

Knowledge about inclusion

8. I know the principles of LISMI, LOE and the UN convention on the rights of persons with disabilities

9. I am able to diagnose a student with SEN

10. I know the different schooling modalities available for students with SEN.

11. I can provide guidance about the organisational proposals which should be included in a School Educational Project in order to develop IE

12. I am able to provide guidance about the methodological adaptations that can be used in class in order to deal with students' diversity

13. I can provide guidance about future professional opportunities for students with SEN

$\begin{array}{llllllll}2.77 & 1.11 & 77 & 42.6 & 55 & 30.4 & 49 & 27.1 \\ 2.65 & 1.07 & 78 & 43.1 & 63 & 34.8 & 40 & 22.1 \\ 2.87 & 1.11 & 68 & 37.4 & 55 & 30.2 & 59 & 32.4 \\ 2.84 & 1.07 & 66 & 36.8 & 61 & 34.1 & 52 & 29.1 \\ 3.05 & 1.02 & 55 & 30.2 & 59 & 32.4 & 68 & 37.3 \\ 2.70 & 1.18 & 80 & 44.2 & 51 & 28.2 & 50 & 27.6 \\ 3.55 & 1.09 & 29 & 15.9 & 51 & 28.0 & 102 & 56 \\ 2.9 & .9 & & & & & & \end{array}$

14. I feel qualified to carry out my work according to the requirements of IE

Total

\subsection{Relationship between Students' Attitudes and Knowledge about IE, Gender and Age}

The relationship between students' attitudes and knowledge about IE and age was studied using the Pearson product-moment correlation coefficient. Preliminary analyses were carried out to guarantee the non-violation of the normality, linearity and homogeneity assumptions. A medium positive correlation was found between attitudes towards IE and participants' age $(r=.320, n=182, p=.000)$ and also between knowledge about IE and age $(r=.511, n=182, p=.000)$. The older participants had greater knowledge and better attitudes. Also, positive attitudes towards IE went hand in hand with greater knowledge about it, with a medium correlation strength $(r=.313, \mathrm{n}=182, p=.000)$.

Similarly, a independent-samples $t$-test was carried out to evaluate the differences in attitudes towards IE and its 
specific knowledge based on gender and the results did not prove to be statistically significant at $p<.05$ level.

\subsection{Differences in Attitudes towards IE as a Function of Students' Academic Year of Study}

In order to examine the differences among attitudes towards IE based on the students' year of study. A one-way between-groups ANOVA was carried out. The analyses proved that differences were statistically significant between attitudes and students' year of study (Table 2). Post-hoc comparisons using the Sheffe test showed that fourth-year students' attitudes $(M=32.2 ; S D=2.33)$ were more positive than those of first-year students $(M=28.85$; $S D=3.37)$ and second-year students $(M=29.52 ; S D=3.46)$. Contrasts also showed that third-year students' attitudes $(M=31.08 ; S D=2.83)$ were more favourable than those of first-year students. The differences between attitudes and year of study were at $p<.01$ level $\left[F(3,181)=5.58, p=.001, \eta \mathrm{p}^{2}=.08\right]$, and the effect size was medium.

It was particularly noticeable that fourth-year students are much more likely to think that IE promotes tolerance and respect towards difference than first-year students $(p=.00)$. This was also observed between forth and third-year students and first-year students $(p<.01)$. Similarly, fourth-year students were more in favour of applying IE in secondary school that those from the first and second year $(p<.01)$. Finally, third-year students were slightly more likely than first year students to agree that IE has more advantages than disadvantages ( $p$ $<.05)$.

Table 2. Students' attitudes towards IE as a function of their year of study

\begin{tabular}{|c|c|c|c|c|c|c|c|c|c|c|c|}
\hline & 1 & & 21 & & 3 & & 4 & & & & \\
\hline & $M$ & SD & $M$ & SD & $M$ & $\mathrm{SD}$ & $M$ & SD & $\begin{array}{l}F(3, \\
181)\end{array}$ & $p$ & $\begin{array}{l}\text { Post } \\
\text { hoc }^{\text {a }}\end{array}$ \\
\hline $\begin{array}{l}\text { Attitudes towards } \\
\text { inclusion }\end{array}$ & & & & & & & & & & & \\
\hline $\begin{array}{l}\text { 1. It is unfair to separate } \\
\text { students with SEN from } \\
\text { the rest of their peers }\end{array}$ & 3.99 & 1.31 & 3.82 & 1.35 & 4.15 & 1.22 & 4.59 & .84 & 2.284 & .081 & \\
\hline $\begin{array}{l}\text { 2. Inclusive education } \\
\text { develops tolerance and } \\
\text { respect among students }\end{array}$ & 4.59 & .52 & 4.36 & .81 & 4.77 & .42 & 4.96 & .19 & 7.596 & $.000 * *$ & $\begin{array}{c}1<4 \\
2<3,4\end{array}$ \\
\hline $\begin{array}{l}\text { 3. I think that all students, } \\
\text { including those with } \\
\text { moderate and severe } \\
\text { disabilities, can learn in } \\
\text { inclusive settings }\end{array}$ & 3.93 & .94 & 3.89 & .98 & 4.06 & .94 & 4.15 & 1.02 & .554 & .646 & \\
\hline $\begin{array}{l}\text { 4. Inclusive education is } \\
\text { also possible in secondary } \\
\text { education }\end{array}$ & 4.41 & .62 & 4.18 & .82 & 4.53 & .68 & 4.85 & .36 & 5.863 & $.001 * *$ & $1,2<4$ \\
\hline $\begin{array}{l}\text { 5. Inclusion has more } \\
\text { advantages than } \\
\text { disadvantages }\end{array}$ & 4.12 & .90 & 4.13 & .97 & 4.51 & .71 & 4.48 & .70 & 2.944 & $.034 *$ & $1<3$ \\
\hline $\begin{array}{l}\text { 6. I am in favour of } \\
\text { inclusion }\end{array}$ & 4.59 & .62 & 4.59 & .54 & 4.68 & .47 & 4.74 & .52 & .636 & .593 & \\
\hline $\begin{array}{l}\text { 7. Inclusion requires the } \\
\text { presence in the classroom } \\
\text { of support educators }\end{array}$ & 4.23 & .80 & 4.51 & .64 & 4.45 & .88 & 4.48 & .70 & 1.470 & .224 & \\
\hline Total & 29.85 & 3.37 & 29.52 & 3.46 & 3.08 & 2.83 & 32.2 & 2.33 & 5.58 & $.001 * *$ & $\begin{array}{c}1,2<4 \\
1<3\end{array}$ \\
\hline
\end{tabular}

Note. ${ }^{\mathrm{a}} 1=$ First year; $2=$ Second year; $3=$ Third year, $4=$ Forth year; $*$ Significant at $p<0.05$ level.; ** Significant at $p<0.01$ level. 


\subsection{Differences in Knowledge about IE as a Function of Students' Academic Year of Study}

The influence on students' knowledge about IE was examined based on their year of study (Table 3). The results of the ANOVA showed statistically significant differences with a large effect size at $p<.01$ level $[F(3,181)=$ $\left.16.37, p=.000, \eta p^{2}=.22\right]$. Post-hoc comparisons revealed that fourth-year students $(M=26.0 ; S D=5.06)$ and third-year students $(M=19.75 ; S D=5.31)$ generally showed greater knowledge about IE than first-year students $(M=17.69 ; S D=6.05)$. The biggest differences were observed between fourth-year students and the rest of the groups, with a noticeably wide range between fourth-year and third-year groups. The contrast analysis showed that knowledge already improves from first-year students to second-year students.

A more detailed analysis showed that students' knowledge of European and Spanish regulations about IE improved in the more senior years, especially between third and fourth-year students compared to first-year students and between fourth-year students and third and second-year students $(p=.00)$. Fourth-year students also showed a better knowledge of the inclusive schooling modalities than the rest of the groups $(p=.00)$. Similarly, a recurrent pattern was observed regarding psychopedagogic assessment $(p=.01)$, guidance on organisational proposals to promote inclusion $(p=.00)$, guidance on socio-professional opportunities to students with SEN ( $p$ $=.00)$ and methodological adaptations $(p=.01)$, with third and fourth-year students having better knowledge than first-year students. This pattern was also observed with the same significance when comparing fourth-year students with third-year students.

Table 3. Students' knowledge about IE as a function of their year of study

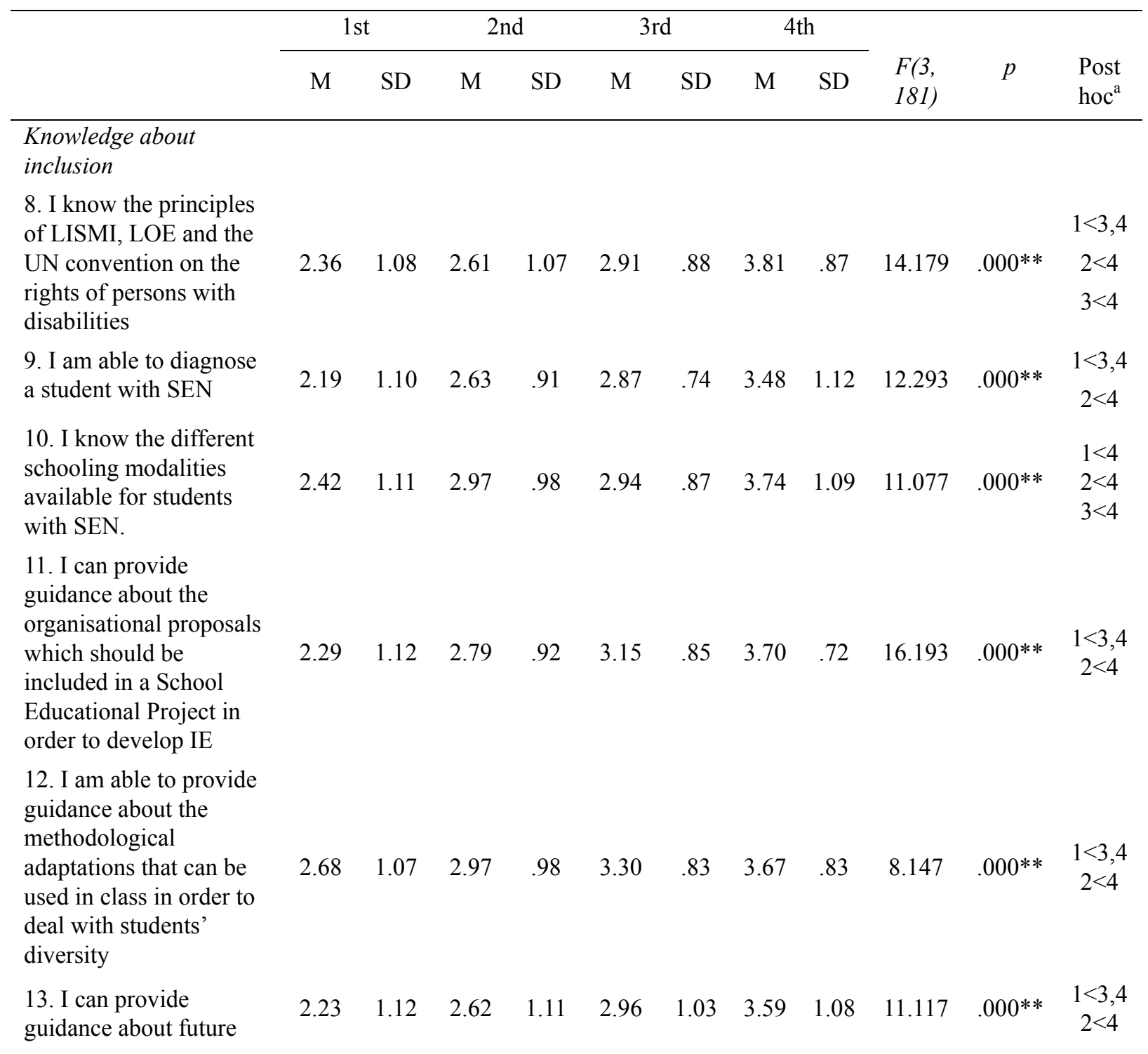


professional

opportunities for

students with SEN

14. I feel qualified to

carry out my work

according to the

3.6

1.16

3.18

1.16

3.51

.88

$4.00 \quad 1.00$

3.207

$.024 *$

$2<4$

requirements of IE

$\begin{array}{lllllllllllll} & 1<3,4 \\ \text { Total } & 17.69 & 6.05 & 19.75 & 5.31 & 19.75 & 5.31 & 26 & 5.06 & 16.37 & .000^{* *} \quad \begin{array}{l}2<4 \\ 1<2 \\ 3<4\end{array} \\ & & & & & & & & & & & \\ 3\end{array}$

Note $^{\cdot \mathrm{a}} 1 \mathrm{st}=$ First year; $2 \mathrm{nd}=$ Second year; $3 \mathrm{rd}=$ Third year, 4 th $=$ Forth year $*$ Significant at $p<0.05$ level. $* *$ Significant at $p<0.01$ level.

\section{Discussion}

\subsection{Future Education Professionals' Attitudes towards IE}

Echoing the results of other studies, future pedagogues taught at the University of Valencia seem to show highly positive attitudes towards IE, even to a greater extent than their peers from other countries in similar studies (Cook, 2002; Gómez \& Infante, 2004; Haq \& Mundia, 2012; Mu et al., 2007). Specifically, some other countries' students show doubts or even rejection towards IE for students with sensory deficits, intellectual impairment, behavioural problems or multiple disabilities (Cook, 2002; Haq \& Mundia, 2012), disabilities (Sharma et al., 2009); or even a more general rejection towards students with low academic performance or with a shy, withdrawn personality (Sharma et al., 2009). Nevertheless, students in our study are chiefly in favour of IE for students with moderate and severe disabilities, both in primary and secondary education.

This research concludes that, based on the sample participants, IE promotes tolerance and respect in all students. Similar results have been provided by Sandoval (2009), who concludes that IE stimulates justice, equality and cooperation. Also Llorent and Llorent (2012) show the existing relationship between those values and students' institutional and social contexts.

Similarly, students' in our study are highly in favour of IE and believe it has more advantages than disadvantages. This data enables us to conclude that they believe in the importance of those attitudes for their professional work, something which has also been pointed out by de Boer, Pijl and Minnaert (2010) and Costello and Boyle (2013).

Some studies have noted, based on future education pedagogues' opinion, that successful IE depends on professionals' initial training (Cook, 2002), professional experience and previous contact with disabled people (de Boer et al., 2010; Sharma et al., 2008), on special education training (Forlin et al., 2010; Sharma et al., 2009) or even on teachers' personal background, aptitudes and qualifications (Cook, 2002). However, our students have highlighted that successful IE depends on the presence of support teachers in the classroom and on the specific role played by class tutors. This is partly along the same lines as a study which identifies influential factors for successful IE such as: (a) lack of personal resources, (b) work volume of ordinary teachers, (c) acceptance of peers and families and (d) risk of lowering academic level of the class (Sharma et al., 2009).

\subsection{Future Professionals' Qualification towards IE}

As for the essential question of future pedagogues' professional qualification, students from the University of Valencia consider they are not trained enough to carry out basic IE tasks, although they are willing to complete their training. These results are along the same lines as those observed in other contexts (Forlin \& Chambers, 2011; Forlin et al., 2010; Forlin, Loreman, et al., 2009; Gokdere, 2012; Sharma et al., 2009).

\subsection{Influence of Demographic Variables such as Gender, Age and Training Received on Students' Attitudes and Knowledge about IE}

As in most comparable international studies, the sample used in our research had a higher level of women than men. Forlin et al. (2009) found small differences in attitudes in favour of female students over male students. In contrast to this, our research did not show such differences regarding attitudes towards IE. Neither were any significant differences regarding knowledge based on gender observed. 
Regarding the variable age, students show a medium bivariate correlation between knowledge about IE and age. That same correlation appears between age and attitudes towards IE. Similarly, Forlin et al. (2009) noted that younger students showed more negative attitudes towards IE than their older peers, although their attitudes improved with training, especially among the former group.

Regarding the training received, this study shows how future pedagogues consider there are significant differences in terms of knowledge about IE between third and fourth-year students and first and second-year students. The same situation is true for their attitudes. This makes us believe that improvements in training affect attitudes towards IE. Other studies also provide evidence of such improvements in attitudes when there is more training about IE (Glumbic et al., 2004; Stella et al., 2007), special education (Forlin et al., 2010), politics and regulations (Forlin \& Chambers, 2011), disabled students' education (Sharma et al., 2008), or postgraduate training (Forlin et al., 2010; Sharma et al., 2009).

Lastly, our research results point out that students consider they have training shortfalls regarding their professional qualification in: (a) diagnosing students with SEN, (b) providing guidance about work to students with SEN, (c) knowledge of political and regulatory bases, (d) providing didactic and organisational guidance to management teams, and (e) knowledge of the different schooling modalities available for students with SEN. Other studies with a similar discourse carried out in different socio-political contexts called for a more complete basic training to fulfil the needs of students who suffer anti-social behaviour, disaffection and bullying (Kyriacou et al., 2013).

\section{Conclusion}

Spain is considered one the most inclusive countries at a European level, both in terms of regulation and in terms of the level of inclusion of students with SEN (Chiner \& Cardona, 2012; Chiner, Cardona, \& Gomez, 2015). The results of this study show the highly positive attitudes of future pedagogues towards all groups with SEN at primary and secondary education. However, the level of training received by these students after the Bologna university reforms does not equip them sufficiently to carry out their work adequately and meet the requirements of a quality IE. Therefore, the future of IE in Spain could be seriously affected. We agree with other international studies (Brandes et al., 2012; Forlin et al., 2010; Forlin, Loreman, et al., 2009; Glumbic et al., 2004; Sharma et al., 2009) that university curriculums need to be revised in order to guarantee a professional qualification which meets the requirements of IE. Such training should also include teaching experience, contact with people with SEN and, in particular, with students with disabilities. Such training should be implemented through specific postgraduate level courses, since it affects the development of positive attitudes towards IE.

This study invites us to carry out further in-depth analysis of its results, paying special attention to the influence other demographic variables may have on the development of positive attitudes, such as teaching internships, cooperation with institutions related to IE, political tendencies or religious beliefs.

We are also trying to expand our sample to other universities from our socio-political context in order to obtain conclusions and recommendations applicable on a more general level.

\section{References}

ANECA. (2005). Libro Blanco. Título de Grado en Pedagogía y Educación Social. Madrid: ANECA.

EADSNE. (2011). Mapping the implementation of policy for inclusive education - An exploration of challenges and opportunities for developing indicators a European Agency for Development in Special Needs Education. Retrieved from http://www.european-agency.org/publications/flyers/mipie /MIPIE-summary-of-proposalsEN.pdf/view

Booth, A., \& Aiscow, M. (2002). Index for Inclusion. Developing learning and participation in schools. London: CSIE.

Brandes, J. A., McWhirter, P. T., Haring, K. A., Crowson, M. H., \& Millsap, C. A. (2012). Development of the Indicators of Successful Inclusion Scale (ISIS): Addressing ecological concerns. Teacher Development, 16(4), 463-488. http://dx.doi.org/10.1080/13664530.2012.717212

Campbell, J., Gilmore, L., \& Cuskelly, M. (2003). Changing student teachers' attitudes towards disability and inclusion. Journal of Intellectual and Developmental Disability, 28(4), 369-379. http://dx.doi.org/10.1080/13668250310001616407

Cardona, M. C., Gómez-Canet, P. F., \& González-Sánchez, M. E. (2000). Cuestionario de Percepciones del Profesor acerca de la Pedagogía Inclusiva. Alicante: Universidad de Alicante.

Chiner, E., \& Cardona, M. C. (2012). Inclusive education in Spain: How do skills, resources, and supports affect 
regular education teachers' perceptions of inclusion? International Journal of Inclusive Education, 17(5), 526-541. http://dx.doi.org/10.1080/13603116.2012.689864

Chiner, E., Cardona, M. C., \& Gómez, J. (2015). Teachers' beliefs about diversity: An analysis from a personal and professional perspective. Journal Of New Approaches In Educational Research, 4(1), 18-23. http://dx.doi.org/10.7821/naer.2015.1.113

Cologon, K. (2012). Confidence in their own ability: Postgraduate early childhood students examining their attitudes towards inclusive education. International Journal of Inclusive Education, 16(11), 1155-1173. http://dx.doi.org/10.1080/13603116.2010.548106

Cook, B. G. (2002). Inclusive Attitudes, Strengths, and Weaknesses of Pre-service General Educators Enrolled in a Curriculum Infusion Teacher Preparation Program. Teacher Education and Special Education: The Journal of the Teacher Education Division of the Council for Exceptional Children, 25(3), 262-277. http://dx.doi.org/10.1177/088840640202500306

Costello, S., \& Boyle, C. (2013). Pre-service Secondary Teachers' Attitudes Towards Inclusive Education. Australian Journal of Teacher Education, 38(4), 8. http://dx.doi.org/10.14221/ajte.2013v38n4.8

de Boer, A., Pijl, S. J., \& Minnaert, A. (2010). Regular primary schoolteachers' attitudes towards inclusive education: a review of the literature. International Journal of Inclusive Education, 15(3), 331-353. http://dx.doi.org/10.1080/13603110903030089

de Boer, A., Pijl, S. J., \& Minnaert, A. (2012). Students' Attitudes towards Peers with Disabilities: A review of the literature. International Journal of Disability, Development and Education, 59(4), $379-392$. http://dx.doi.org/10.1080/1034912X.2012.723944

Forlin, C., \& Chambers, D. (2011). Teacher preparation for inclusive education: Increasing knowledge but raising concerns. Asia-Pacific Journal of Teacher Education, 39(1), 17-32. http://dx.doi.org/10.1080/1359866x.2010.540850

Forlin, C., Garcia Cedillo, I., Romero-Contreras, S., Fletcher, T., \& Rodriguez Hernandez, H. J. (2010). Inclusion in Mexico: Ensuring supportive attitudes by newly graduated teachers. International Journal of Inclusive Education, 14(7), 723-739. http://dx.doi.org/10.1080/13603111003778569

Forlin, C., Loreman, T., Sharma, U., \& Earle, C. (2009). Demographic differences in changing pre-service teachers' attitudes, sentiments and concerns about inclusive education. International Journal of Inclusive Education, 13(2), 195-209. http://dx.doi.org/10.1080/13603110701365356

Forlin, C., Sharma, U., \& Loreman, T. (2009). An International Comparison of Pre-service Teacher Attitudes towards Inclusive Education. Disability Studies Quarterly, 27(4).

Glumbic, N., Kaljaca, S., \& Brojcin, B. (2004). The attitude of future special educators towards inclusive education of children with mild intellectual disability. Journal of Intellectual Disability Research, 48, 505-505.

Gokdere, M. (2012). A Comparative Study of the Attitude, Concern, and Interaction Levels of Elementary School Teachers and Teacher Candidates towards Inclusive Education. Kuram Ve Uygulamada Egitim Bilimleri, 12(4), 2800-2806.

Gómez, V., \& Infante, M. (2004). Education student's attitudes towards integrating people with disabilities and multicultural education. Cultura y Educación, 16(4), 371-383. http://dx.doi.org/10.1174/1135640042802455

Haq, F. S., \& Mundia, L. (2012). Comparison of Brunei Preservice Student Teachers' Attitudes to Inclusive Education and Specific Disabilities: Implications for Teacher Education. Journal of Educational Research, 105(5), 366-374. http://dx.doi.org/10.1080/00220671.2011.627399

Kim, J.-R. (2011). Influence of teacher preparation programmes on preservice teachers' attitudes toward inclusion. International Journal of Inclusive Education, 15(3), 355-377. http://dx.doi.org/10.1080/13603110903030097

Kyriacou, C., Avramidis, E., Stephens, P., \& Werler, T. (2013). Social pedagogy in schools: Student teacher attitudes in England and Norway. International Journal of Inclusive Education, 17(2), 192-204. http://dx.doi.org/10.1080/13603116.2011.629689

Lambe, J. (2011). Pre-service education and attitudes towards inclusion: the role of the teacher educator within a permeated teaching model. International Journal of Inclusive Education, 15(9), 975-999. http://dx.doi.org/10.1080/13603110903490705 
Lawshe, C. H. (1975). A quantitative approach to content validity. Personnel Psychology, 28(4), 563-575. http://dx.doi.org/10.1111/j.1744-6570.1975.tb01393.x

LIONDAU. (2013). Ley 51/2003, de 2 de diciembre, de Igualdad de Oportunidades, no Discriminación y Accesibilidad Universal de las Personas con Discapacidad. Boletín Oficial del Estado, Diciembre 3.

LISMI. (1982). Ley 13/1982, de 7 de abril, de Integración Social de los Minusválidos. Boletín Oficial del Estado, April 20.

Llorent-Bedmar, V., \& Llorent García, V. J. (2012). La inclusión educativa desde la perspectiva de futuros maestros en Brasil, Cabo Verde y España. Revista de Educación Inclusiva, 5(2), 43-59.

López, M. (2009). La inclusión educativa de los alumnos con discapacidades graves y permanentes en la Unión Europea. RELIEVE, 15(1), 1-20.

López-Torrijo, M., \& Mengual-Andrés, S. (2014). Students with Severe, Permanent Disabilities and Their Educational Inclusion in Spain. International Education Studies, 7(2), 91-105. http://dx.doi.org/10.5539/ies.v7n2p91

López-Torrijo, M., \& Mengual-Andrés, S. (2015). An Attack on Inclusive Education in Secondary Education. Limitations in Initial Teacher Training in Spain. Journal Of New Approaches In Educational Research, 4(1), 9-17. http://dx.doi.org/10.7821/naer.2015.1.100

Loreman, T., Earle, C., Sharman, U., \& Forlin, C. (2007). The development of an instrument for measuring pre-service teachers' sentiments, attitudes, and concerns about inclusive education. International Journal of Special Education, 22(2), 150-159.

LOGSE. (1990). Ley 1/1990, de 3 de octubre, de Ordenación General del Sistema Educativo. Boletín Oficial del Estado, October 4.

LOCE. (2002). Ley Orgánica 10/2002, de 23 de diciembre, de Calidad de la Educación. Boletín Oficial del Estado, December 24.

LOE. (2006). Ley Orgánica 2/2006, de 3 de mayo, de Educación. Boletín Oficial del Estado, May 4.

MECD. (2012). Datos y Cifras Curso Escolar 2012/2013. Madrid: Ministerior de Educación. Retrived from https://sede.educacion.gob.es/publiventa/detalle.action?cod=15333

Mu, K., Franck, L. G., \& Konz, C. (2007). Attitudes of entry level occupational therapy doctoral students towards inclusion for students with disabilities. Australian Occupational Therapy Journal, 54, S66-S73. http://dx.doi.org/10.1111/j.1440-1630.2006.00590.x

Opertti, R., \& Brady, J. (2011). Developing inclusive teachers from an inclusive curricular perspective. PROSPECTS, 41(3), 459-472. http://dx.doi.org/10.1007/s11125-011-9205-7

Rao, S., Cardona, M. C., \& Chiner, E. (2014). Special Education today in Spain. Advances in Special Education, $28,147-180$. http://dx.doi.org/10.1108/S0270-401320140000028012

Sandoval, M. (2009). Concepciones de los estudiantes de magisterio sobre la inclusión educativa. Aula abierta, $37(1), 79-88$.

Sharma, U., Forlin, C., \& Loreman, T. (2008). Impact of training on pre-service teachers' attitudes and concerns about inclusive education and sentiments about persons with disabilities. Disability \& Society, 23(7), 773-785. http://dx.doi.org/10.1080/09687590802469271

Sharma, U., Forlin, C., Loreman, T., \& Earle, C. (2006). Pre-service teachers' attitudes, concerns and sentiments about inclusive education: An international comparison of the novice preservice teacher. International Journal of Special Education, 21(2), 80-93.

Sharma, U., Moore, D., \& Sonawane, S. (2009). Attitudes and concerns of pre-service teachers regarding inclusion of students with disabilities into regular schools in Pune, India. Asia-Pacific Journal of Teacher Education, 37(3), 319-331. http://dx.doi.org/10.1080/13598660903050328

SC. (1978). Spanish Constitution, of December 27, 1978 (Constitución Española). Official Spanish Gazette (Boletín Oficial del Estado - BOE) n. 311, of December 29

Stella, C. S. C., Forlin, C., \& Lan, A. M. (2007). The influence of an inclusive education course on attitude change of pre-service secondary teachers in Hong Kong. Asia-Pacific Journal of Teacher Education, 35(2), 161-179. http://dx.doi.org/10.1080/13598660701268585 
UN. (2006). Convention on the Rights of Persons with Disabilities. United Nations: UN.

UNESCO. (1994). The Salamanca Statement and framework for action on special needs education. Paris.

UNESCO. (2008). Inclusive education: The way of the future. 48th session of the International Conference on Education. Genova.

\section{Copyrights}

Copyright for this article is retained by the author(s), with first publication rights granted to the journal.

This is an open-access article distributed under the terms and conditions of the Creative Commons Attribution license (http://creativecommons.org/licenses/by/3.0/). 